\title{
PENGOLAHAN LIMBAH CAIR INDUSTRI TAHU DI DESA KALISARI KECAMATAN CILONGOK DENGAN METODE MULTI SOIL LAYERING
}

\author{
Irmanto, Suyata \\ Program Studi Kimia, Fakultas Sains dan Teknik, Universitas Jenderal Soedirman \\ E-mail: irmpwt@yahoo.com
}

\begin{abstract}
Tofu industry is one of the industries which causing pollution on the environment especially water environment. The amount of wastewater-dumped and the content of organic substances could damage the water ecosystem. Multi Soil Layering (MSL) as one of alternative method is used in order to remove the tofu industrial wastewater pollution. MSL is a method of wastewater treatment that enhances the function of soils to purify wastewater.

The research aimed to determine optimum loading rate and efficiency of MSL system to remove TSS, BOD and COD. The wastewater on the MSL system is loaded at the loading rate varieties, i.e: $160,320,480,640$, and $800 \mathrm{~lm}^{-2}$ day $^{-1}$, and the aeration was applied for 8 a day at $1296 \mathrm{ld}^{-1}$.

The results revealed that optimum loading rate was $320 \mathrm{~lm}^{-2}$ day $^{-1}$ and efficiency of MSL system to remove TSS, BOD and COD were $78.62 \% ; 98,89 \%$ and $95,53 \%$ respectively.
\end{abstract}

Keywords: MSL, tofu industrial, wastewater

\section{PENDAHULUAN}

Kabupaten Banyumas adalah salah satu kabupaten di daerah Eks karesidenan Banyumas yang mempunyai beberapa sentra industri tahu. Salah satu sentra industri tahu ini terletak $15 \mathrm{~km}$ dari pusat kota Purwokerto, tepatnya di Desa Kalisari Kecamatan Cilongok. Desa Kalisari mempunyai sekitar 374 UKM (Usaha Kecil Menengah) yang menekuni pembuatan tahu. Berdasarkan data yang diperoleh dari kantor Kepala Desa Kalisari, rata-rata seluruh UKM menghasilkan limbah cair sekitar $40 \mathrm{~m}^{3}$. Limbah cair tersebut langsung dialirkan ke sungai tanpa diolah terlebih dahulu dan menimbulkan bau yang busuk.

Menurut Surat Kabar Radar Banyumas edisi Selasa 6 September 2005, dari hasil investigasi diperoleh suatu kesimpulan bahwa limbah cair industri tahu di Desa Kalisari telah mencemari seluruh aliran air seperti sungai dan selokan. Mengingat air sungai tersebut diperlukan untuk irigasi pertanian, perikanan, dan sebagian besar industri ini berlokasi di pemukiman yang penduduknya padat dan di dekat Daerah Aliran Sungai (DAS). Oleh karena itu, suatu teknik yang efektif, murah, dan dapat digunakan sebagai Instalasi Pengolahan Air Limbah (IPAL) sangat dibutuhkan segera.

Berbagai teknik pengolahan limbah cair telah dikembangkan seperti adsorpsi dengan karbon aktif, oksidasi kimiawi, dan digesti biologis. Namun, masingmasing teknik ini penggunaannya terbatas dan kurang menguntungkan. Sebagai contoh, karbon aktif hanya melibatkan adsorpsi polutan tanpa dekomposisi. Oksidasi kimia tidak dapat memineralisasi semua senyawa organik dan hanya cocok untuk menghilangkan polutan dengan konsentrasi tinggi. Pengolahan secara biologis memiliki 
kelemahan yaitu kecepatan reaksi lambat, pembuangan lumpur aktif yang sulit, $\mathrm{pH}$ dan temperatur harus dikontrol. Suatu teknik pengolahan limbah organik yang lebih efektif, efisien, mudah, dan murah perlu dikembangkan yaitu metode Multi Soil Layering (MSL).

Sistem MSL merupakan suatu sistem yang menggunakan tanah andosol, zeolit, kerikil (gravels), dan arang tempurung kelapa sebagai sumber karbon serta menggunakan pipa aerasi sebagai sumber oksigen. Lapisan tanah dan zeolit disusun dengan pola seperti batu bata untuk mencegah terjadinya penyumbatan dan pembentukan lapisan impermeable (Wakatsuki et al., 1993).

Bahan-bahan yang diperlukan untuk membuat sistem ini tersedia secara lokal sehingga disamping teknik ini murah juga memanfaatkan sumberdaya alam Kabupaten Banyumas. Zeolit diperoleh dari Kecamatan Lumbir, sedangkan tanah andisol dari bukit Cendana Baturraden.

Sistem MSL dikembangkan untuk meningkatkan fungsi tanah dalam pengolahan limbah cair biogenik sebelum dilepas ke badan perairan. Proses biodegradasi komponen air limbah dalam sistem MSL berlangsung melalui bantuan bakteri-bakteri di bawah kondisi aerobik maupun anaerobik. Zona aerobik terjadi pada lapisan kerikil dan zeolit serta antar muka antara lapisan zeolit dan lapisan tanah. Zona anaerobik terjadi pada lapisan campuran tanah dengan arang tempurung kelapa.

Berdasarkan hasil penelitian Wakatsuki et al. (2001), metode MSL dapat menurunkan BOD dan COD sungai Uya di kepulauan Oki, Jepang sampai 90 $\%$. Luanmanee et al. (2000) menggunakan metode MSL untuk pengolahan limbah domestik dari cafetaria dan toilet Universitas Kasetsart, Thailand dan dapat menurunkan BOD sebesar 98,8\% dan COD sebesar 93,6\%. Menurut Wakatsuki et al. (1993), sistem
MSL efektif digunakan untuk pengolahan limbah selama 12,8 tahun. Namun, mungkin saja lebih pendek atau lebih panjang tergantung pada mutu limbah, kandungan dan jenis dari material organik, temperatur dan manajemen dari sistem tersebut.

Berdasarkan hal tersebut, maka perlu dilakukan penelitian untuk mengembangkan metode MSL dalam pengolahan limbah cair industri tahu. Adapun yang menjadi masalah dalam penelitian ini adalah: Berapakah kecepatan pengisian (loading) optimum air limbah ke dalam sistem MSL untuk memperoleh persentase penurunan BOD, COD, dan TSS yang optimum?, Berapa persenkah penurunan BOD, COD dan TSS limbah cair industri tahu setelah dilakukan pengolahan dengan sistem MSL? Apakah nilai BOD, COD, dan TSS limbah cair industri tahu di bawah baku mutu setelah dilakukan pengolahan dengam sistem MSL ?

\section{METODE PENELITIAN Bahan dan Alat.}

Alat- alat yang digunakan dalam penelitian ini adalah: instrumen MSL, botol winkler, alat-alat gelas, dan kertas saring.

Bahan-bahan kimia yang digunakan adalah: $\mathrm{MgSO}_{4}$, alkali azida, $\mathrm{MnSO}_{4}, \mathrm{H}_{2} \mathrm{SO}_{4}$ pekat, $\mathrm{HgSO}_{4}, \mathrm{KMnO}_{4}$, KI, $\quad \mathrm{Na}_{2} \mathrm{~S}_{2} \mathrm{O}_{3}, \quad \mathrm{Na}_{2} \mathrm{CO}_{3}, \quad \mathrm{KH}_{2} \mathrm{PO}_{4}$, $\mathrm{Na}_{2} \mathrm{HPO}_{4}, \mathrm{NH}_{4} \mathrm{Cl}$, dan aquadest

\section{Prosedur Penelitian}

\section{Pembuatan Sistem MSL}

Instrumen sistem MSL dibuat dengan konstruksi seperti dapat dilihat pada Gambar 1. Bak akrilik dengan ukuran dimensi dalam $(50 \mathrm{~cm} \mathrm{x} 15 \mathrm{~cm} \mathrm{x}$ $50 \mathrm{~cm}$ ) disiapkan. Dasar bak diisi dengan batu kerikil dengan ketinggian $4 \mathrm{~cm}$, lalu seluruh permukaan batu kerikil ditutup dengan net. Lapisan kedua berikutnya 
diisi zeolit (berdiameter 2-3 $\mathrm{mm}$ ) dengan ketinggian $4 \mathrm{~cm}$. Empat buah bingkai triplek masing-masing dengan dimensi dalam $(4 \mathrm{~cm} \times 9 \mathrm{~cm} \times 15 \mathrm{~cm})$ dipasang sejajar pada jarak masing-masing $3 \mathrm{~cm}$. Ke dalam bingkai triplek dialas dengan plastik net halus yang dapat membungkus blok-blok lapisan campuran tanah. Campuran tanah dan arang tempurung kelapa dengan perbandingan $1: 1$ diisi ke dalam bingkai triplek, lalu dipadatkan.
Bingkai triplek diangkat dan lapisan selanjutnya diisi dengan zeolit setinggi 4 $\mathrm{cm}$. Lapisan-lapisan lain diisi dengan cara yang sama sampai membentuk lima lapisan blok-blok tanah. Antara lapisan ke 3 dan 4 dipasang pipa aerasi (diameter $1,5 \mathrm{~cm}$ ) dengan jarak antar lubang aerasi $5 \mathrm{~cm}$ dan ukuran diameter lubang 0,5 $\mathrm{mm}$.

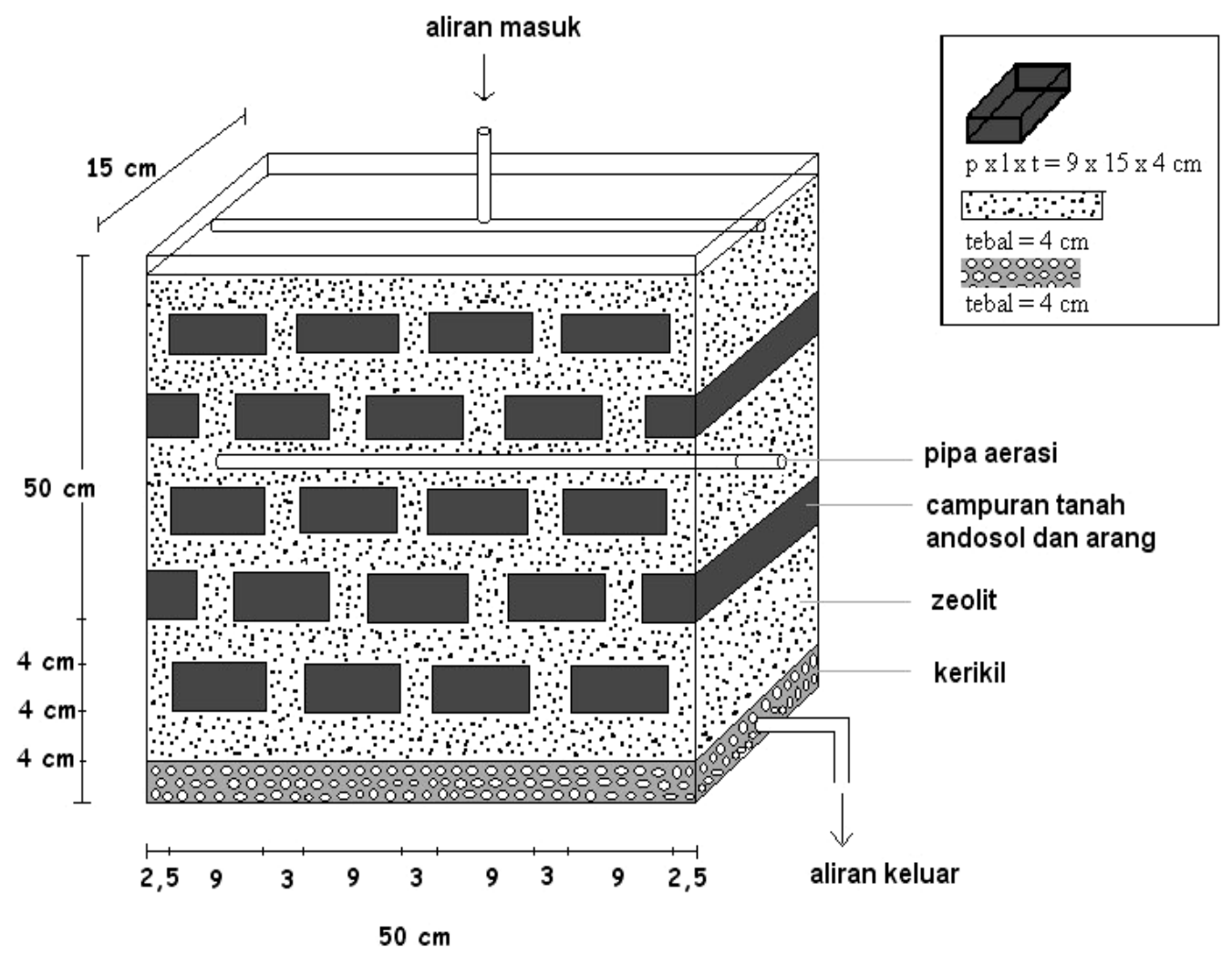

Gambar 1. Instrumen Multi Soil Layering

\section{Penentuan Kecepatan Pengisian Air} Limbah ke Dalam Sistem MSL

1. Penentuan nilai BOD, COD, dan TSS dalam limbah cair industri tahu sebelum diolah (treatment) dengan sistem MSL.
(a) masing-masing
parameter dianalisis sesuai dengan metode analitik.
(b) pengukuran dilakukan secara triplo.

2. Air limbah diisikan ke dalam sistem MSL selama 24 jam per hari pada berbagai variasi kecepatan pengisian $\left(160,320,480,640,800 \mathrm{~lm}^{-2} \mathrm{~h}^{-1}\right)$.

3. Penentuan nilai BOD, COD, dan TSS dalam limbah cair industri tahu pada berbagai variasi kecepatan pengisian setelah diolah (treatment) dengan sistem MSL. 
(a) masing-masing parameter dianalisis sesuai dengan metode analitik

(b) pengukuran dilakukan secara triplo

4. Perhitungan persentase penurunan BOD, COD, dan TSS dalam limbah cair industri tahu pada berbagai variasi kecepatan pengisian.

\section{Penentuan Efisiensi Sistem MSL untuk Menurunkan BOD, COD dan TSS Limbah Cair Industri Tahu.}

1. Pada kecepatan pengisian optimum dan dengan cara yang sama ditentukan persentase penurunan nilai BOD, COD, dan TSS.

Sampling dilakukan seminggu sekali selama 3 bulan.

\section{Metode Analisis}

Penentuan BOD (APHA, 1995)

Penentuan BOD dilakukan dengan menggunakan metode titrasi Winkler, dimana kadar BOD dihitung dengan rumus : $\mathrm{BOD}=\mathrm{DO}_{(0)}-\mathrm{DO}_{(5)}$

\section{Penentuan DO $(0)$}

Dipipet $50 \quad \mathrm{ml}$ sampel, dimasukkan ke dalam labu ukur $1000 \mathrm{ml}$ ditambahkan masing-masing $1 \mathrm{~mL}$ buffer posfat, $\mathrm{MgSO}_{4}, \mathrm{CaCl}_{2}$ dan $\mathrm{FeCl}_{3}$ dan diencerkan dengan akuades sampai tanda batas. Dipindahkan ke beker gelas 1000 ml lalu diaerasi selama 15 menit. Dimasukkan ke dalam botol Winkler dan ditutup, tambahkan masing-masing $1 \mathrm{ml}$ alkali azida dan $\mathrm{MnSO}_{4} 10 \%$, tutup lalu kocok dengan membalik-balikan botol winkler. Dibiarkan selama 10 menit lalu dipindahkan ke erlenmeyer. Ditambahkan $1 \mathrm{ml} \mathrm{H}_{2} \mathrm{SO}_{4}$ pekat, dikocok dan dititrasi dengan tiosulfat hingga kuning pucat. Ditambahkan beberapa tetes amilum $1 \%$ kemudian titrasi dilanjutkan sampai warna biru tepat hilang.

\section{Penentuan DO (5)}

Sampel yang telah diaerasi pada pengerjaan $\mathrm{DO}_{(0)}$ dimasukkan ke dalam botol winkler dan ditutup rapat tanpa adanya udara dan disimpan 5 hari. Kemudian dititrasi dengan cara yang sama pada penetuan $\mathrm{DO}_{(0)}$. Kadar oksigen terlarut dapat dihitung dengan rumus :

Kadar $\mathrm{O}_{2}(\mathrm{ppm})$

$=\underline{(\mathrm{mL} \times \mathrm{N}) \text { pentiter } \times 8000}$ $\mathrm{mL}$ sampel -2

$\mathrm{DO}=$ kadar $\mathrm{O}_{2}(\mathrm{ppm}) \mathrm{x}$ faktor pengenceran

\section{Penentuan COD (APHA, 1995)}

Penentuan COD dilakukan dengan menggunakan metode titrasi iodometri. $\quad 50 \mathrm{ml}$ akuades sebagai blanko dan $50 \mathrm{ml}$ sampel dimasukkan ke dalam erlenmeyer $250 \mathrm{ml}$ ditambahkan $0,1 \mathrm{~g} \mathrm{HgSO}_{4}$ dan $5 \mathrm{ml} \mathrm{KMnO}_{4}$ 0,1 M. Ditutup, lalu dipanaskan selama 1 jam dalam penangas air, didinginkan dan ditambahkan $5 \mathrm{ml} \mathrm{KI} 10 \%$ dan $10 \mathrm{ml}$ $\mathrm{H}_{2} \mathrm{SO}_{4} 4 \mathrm{~N}$. Kemudian dititrasi dengan larutan standar $\mathrm{Na}_{2} \mathrm{~S}_{2} \mathrm{O}_{3}$ sampai warna kuning pucat. Setelah itu ditambahkan beberapa tetes amilum $1 \%$ kemudian dititrasi kembali sampai warna biru hilang. Kadar COD dapat dihitung dengan rumus :

$$
\begin{aligned}
& \text { Kadar COD (ppm) } \\
& =\frac{(\mathrm{A}-\mathrm{B}) \times \mathrm{N} \text { x } 8000}{\mathrm{~mL} \text { sampel }}
\end{aligned}
$$

dimana : $\mathrm{A}=\mathrm{ml}$ pentiter untuk blanko

$$
\mathrm{B}=\text { ml pentiter untuk sampel }
$$$$
\mathrm{N}=\text { normalitas } \mathrm{Na}_{2} \mathrm{~S}_{2} \mathrm{O}_{3}
$$

\section{Penentuan TSS (APHA, 1995)}

Letakkan kertas saring ke dalam alat penyaring, bilas dengan air suling sebanyak $20 \mathrm{ml}$ dan operasikan alat penyaring. Ulangi pembilasan hingga bersih dari partikel-partikel halus kertas saring. Ambil kertas saring dan letakkan di atas tempat khusus kertas saring. 
Keringkan kertas saring tersebut di dalam oven pada temperatur $103-105^{\circ} \mathrm{C}$ selama 1 jam. Dinginkan dalam desikator selama 10 menit. Timbang dengan neraca analitik hingga diperoleh berat tetap, misalnya B mg. Letakkan kertas saring tersebut di dalam desikator. Saring sampel dengan menggunakan kertas saring tersebut, kemudian residu tersuspensi dibilas dengan air suling sebanyak $10 \mathrm{ml}$ dan dilakukan tiga kali pembilasan. Ambil kertas saring dan taruh di tempat khusus yang bersih dan kering. Keringkan di dalam alat pengering pada temperatur $103-105^{\circ} \mathrm{C}$ selama 1 jam. Dinginkan dalam desikator selama 10 menit. Timbang dengan neraca analitik hingga diperoleh berat tetap, misalnya A mg. Kadar TSS dapat dihitung dengan rumus :

$\mathrm{mg} / \mathrm{l} \mathrm{residu} \mathrm{tersuspensi}$

$=\frac{(\mathrm{A}-\mathrm{B}) \times 1000}{\mathrm{~mL} \text { contoh }}$

dimana :

$\mathrm{A}=$ berat kertas saring berisi residu tersuspensi (mg)

$\mathrm{B}=$ berat kertas saring kosong $(\mathrm{mg})$

\section{Analisis Data}

Data yang dikumpulkan adalah nilai BOD, COD, dan TSS limbah cair industri tahu sebelum dan setelah dilakukan pengolahan dengan sistem MSL. Dari data tersebut dihitung persentase penurunan $\mathrm{BOD}, \mathrm{COD}$, dan TSS setelah dilakukan pengolahan dengan sistem MSL. Persentase penurunan dihitung dengan rumus:

Kadar (\%)

$=$ konsentrasi awal - konsentrasi akhir $\mathrm{x}$ 100\%

\section{HASIL DAN PEMBAHASAN}

Sistem pengelolaan limbah cair pada umumnya mempunyai prinsip yaitu menghilangkan atau mengurangi zat-zat pencemar dengan berbagai cara seperti filtrasi, koagulasi dan menggunakan lumpur aktif. Sebelum limbah cair dibuang ke lingkungan harus memenuhi beberapa syarat atau harus sesuai dengan standar Baku Mutu Air Limbah yang telah ditetapkan oleh Peraturan Daerah. Baku Mutu Air Limbah adalah ukuran batas atau kadar unsur pencemar dan atau jumlah unsur pencemar yang diperbolehkan keberadaannya dalam air limbah yang akan dibuang ke lingkungan (Bappedalda Jateng, 2004). Peraturan ini ditetapkan oleh Pemerintah Daerah Jawa Tengah dengan tujuan untuk mencegah atau mengurangi terjadinya pencemaran air dan mewujudkan kualitas air yang sesuai dengan peruntukannya.

Salah satu metode pengelolaan limbah yang diharapkan dapat memenuhi standar Baku Mutu Air Limbah adalah metode Multi Soil Layering atau MSL. Metode MSL diujicobakan pada limbah cair industri tahu Desa Kalisari Kecamatan Cilongkok Kabupaten Banyumas.

Baku Mutu Air Limbah Industri Tahu yang telah ditetapkan dalam Peraturan Daerah menggunakan beberapa parameter antara lain Temperatur, Biochemical Oxygen Demand (BOD), Chemical Oxygen Demand (COD), Total Suspended Solid (TTS), dan pH. Kadar maksimum dan beban pencemaran maksimum limbah cair industri tahu dapat dilihat pada Tabel 1. 
Tabel 1. Standar Baku Mutu Air Limbah Industri Tahu

\begin{tabular}{clcc}
\hline No & \multicolumn{1}{c}{ Parameter } & $\begin{array}{c}\text { Kadar Maksimum } \\
(\mathrm{mg} / \mathrm{l})\end{array}$ & $\begin{array}{c}\text { Beban Pencemaran Maksimum } \\
(\mathrm{kg} / \mathrm{ton})\end{array}$ \\
\hline 1 & Temperatur & $38^{0} \mathrm{C}$ & - \\
2 & BOD & 150 & 3 \\
3 & COD & 275 & 5,5 \\
4 & TSS & 100 & 2 \\
5 & pH & & $6,0-9,0$ \\
6 & Debit Maksimum & & $20 \mathrm{~m}^{3} /$ ton kedelai \\
\hline
\end{tabular}

Sumber: Bappedalda Jateng 2004

\section{Penentuan Kecepatan Pengisian Optimum Limbah Cair Industri Tahu ke dalam Sistem MSL}

Sebelum dilakukan penentuan kecepatan optimum sistem MSL dikondisikan selama 2 minggu atau 14 hari. Limbah cair industri tahu yang dialirkan kedalam sistem MSL, diencerkan terlebih dahulu sebanyak 11 kali yaitu 1 liter limbah cair industri tahu dicampur dengan 10 liter air. Limbah cair industri tahu secara bertahap dipekatkan sampai 6 kali, yaitu 1 liter limbah cair industri tahu dicampur dengan 5 liter air. Pengondisian sistem MSL ini bertujuan agar mikroorganisme dan seluruh elemen-elemen yang menyusun sistem MSL dapat beradaptasi secara baik dengan limbah cair industri tahu sehingga dapat melakukan dekomposisi dengan baik.

Sistem MSL yang telah mengalami pengondisian selama 2 minggu kemudian diisi limbah cair industri tahu dengan kecepatan 160, 320, 480, 640 dan $8001 \mathrm{~m}^{-2}$ hari $^{-1}$ selama 24 jam penuh. Untuk mengetahui kecepatan optimum, dilakukan sampling setiap dua hari sekali untuk satu kecepatan alir kemudian dilakukan analisis pada setiap penyampingan yang meliputi nilai TSS, BOD, COD dan $\mathrm{pH}$ sebelum dan sesudah dioleh dengan sistem MSL. Hasil analisis limbah cair industri tahu sebelum dan sesudah dioleh dengan sistem MSL dapat dilihat pada Tabel 2.

Tabel 2. Hasil analisis limbah cair industri tahu sebelum dan sesudah diolah dengan sistem MSL pada penentuan kecepatan pengisian optimum

\begin{tabular}{|c|c|c|c|c|c|c|c|c|}
\hline \multirow{3}{*}{$\begin{array}{l}\text { Kecepatan Pengsisian } \\
\left(1 \mathrm{~m}^{-2} \text { hari }^{-1}\right)\end{array}$} & \multicolumn{4}{|c|}{ Sebelum } & \multicolumn{4}{|c|}{ Sesudah } \\
\hline & \multirow[t]{2}{*}{$\mathrm{pH}$} & \multicolumn{3}{|c|}{$\begin{array}{c}\text { Konsentrasi rata-rata } \\
\left(\mathrm{mg} \mathrm{l}^{-1}\right)\end{array}$} & \multirow[t]{2}{*}{$\mathrm{pH}$} & \multicolumn{3}{|c|}{$\begin{array}{l}\text { Konsentrasi rata-rata } \\
\qquad\left(\mathrm{mg} \mathrm{l}^{-1}\right)\end{array}$} \\
\hline & & TSS & BOD & COD & & TSS & BOD & COD \\
\hline 160 & 4,9 & 750 & 3333,6 & 9270 & 7,4 & 150 & 23,04 & 48 \\
\hline 320 & 4,7 & 820 & 3595,05 & 7860 & 7,2 & 150 & 51,72 & 36 \\
\hline 480 & 4,7 & 690 & 3993,6 & 8520 & 7,2 & 180 & 40,08 & 156 \\
\hline 640 & 4,7 & 600 & 3957,6 & 10516 & 6,9 & 180 & 68,76 & 294 \\
\hline 800 & 4,7 & 330 & 3426 & 14880 & 6,3 & 180 & 216 & 1590 \\
\hline
\end{tabular}


Berdasarkan Tabel 4, dapat dilihat bahwa sistem MSL dapat bekerja dengan baik dalam dekomposisi limbah cair industri tahu yaitu menaikkan $\mathrm{pH}$ serta mampu menurunkan nilai TSS, BOD, COD. Menurut data yang diperoleh dari hasil analisis, urutan kecepatan pengisian dalam menaikkan $\mathrm{pH}$ adalah 160,320 , 480, dan $800 \mathrm{~lm}^{-2}$ hari $^{-1}$. sesudah dioleh dengan metode MSL, pH berada pada rentang 6,3 $\left(800 \mathrm{~lm}^{-2}\right.$ hari $\left.^{-1}\right)$ sampai 7,4 (160 $\mathrm{lm}^{-2}$ hari $\left.^{-1}\right)$ sudah sesuai dengan standar Baku Mutu Air Limbah Industri Tahu yang berada dalam rentang $\mathrm{pH}$ 6,0 - 9,0. kadar TSS setelah diolah pada kecepatan pengisian $320 \mathrm{~lm}^{-2}$ hari $^{-1}$ adalah $120 \mathrm{mg} \mathrm{l}^{-1}$ (lampiran 3), nilai ini sudah mendekati standar Baku Mutu Air Limbah Industri Tahu yaitu $100 \mathrm{mg}^{-1}$.

Nilai atau kadar TSS, BOD dan COD pada kecepatan pengisian tertentu telah memenuhi Standar Baku Mutu air Limbah yang telah ditetapkan oleh Bappedalda Jawa Tengah seperti yang telah dicantumkan pada Tabel 3. persentase penurunan rata-rata nilai TSS, BOD dan COD dalam setiap kecepatan pengisian dapat dilihat pada Gambar 2.

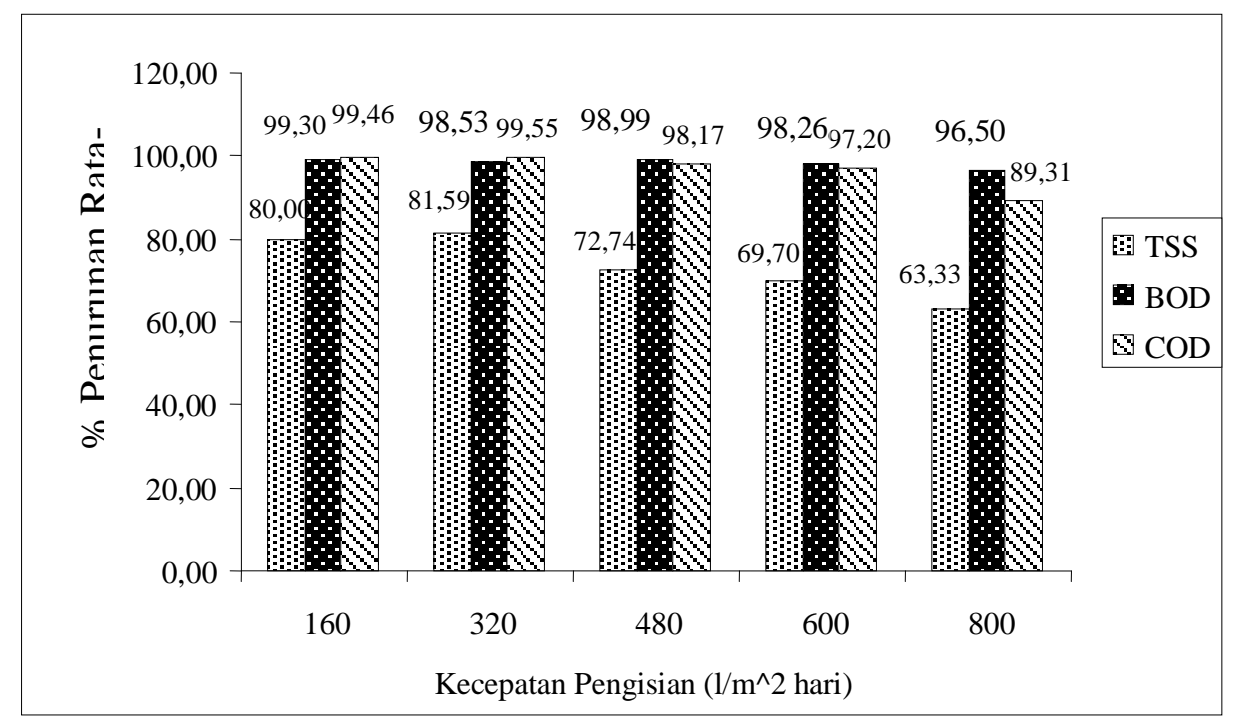

Gambar 2. Grafik persentase penurunan kadar TSS, BOD dan COD limbah cair industri tahu pada berbagai variasi kecepatan pengisian MSL

Berdasarkan Gambar 2, persentase penurunan kadar TSS yang tertinggi diperoleh pada saat kecepatan pengisian $320 \mathrm{~lm}^{-2}$ hari $^{-1}$ yaitu 81,59\% dan yang terendah pada $800 \mathrm{~lm}^{-2}$ hari $^{-1}$ yaitu $63,33 \%$.

Penurunan nilai BOD terjadi secara bertahap dari kecepatan pengisian yang terendah $160 \mathrm{~lm}^{-2}$ hari $^{-1}$ sampai kecepatan tertinggi $800 \quad \mathrm{~lm}^{-2}$ hari $^{-1}$. Persentase penurunan nilai BOD tertinggi diperoleh pada kecepatan pengisian 160 $1 \mathrm{~m}^{-2}$ hari $^{-1}$ sebesar $99,30 \%$ dan yang terendah pada kecepatan pengisian 800 $\mathrm{lm}^{-2}$ hari $^{-1}$ sebesar 96,50\%. Persentase penurunan nilai COD tertinggi diperoleh pada kecepatan pengisian $320 \mathrm{~lm}^{-2}$ hari $^{-1}$ yaitu 99,55 \% dan paling rendah pada kecepatan $800 \mathrm{~lm}^{-2}$ hari $^{-1}$ sebesar 89,31 $\%$. Persentase rata-rata penurunan nilai TSS, BOD dan COD dalam penentuan kecepatan pengisian optimum limbah cair industri tahu yang tinggi menunjukkan bahwa proses dekomposisi limbah dalam sistem MSL telah berlangsung dengan baik. 
Grafik persentase penurunan kadar TSS, BOD dan COD (Gambar 2) memperlihatkan semakin besar kecepatan pengisian persentase penurunan semakin kecil. Hal ini terjadi karena semakin cepat limbah cair industri tahu masuk ke dalam sistem MSL (kecepatan pengisian semakin besar) maka waktu kontak antara limbah cair industri tahu dengan zeolit dan lapisan tanah semakin cepat, sedangkan untuk mendekomposisi limbah cair industri tahu, zeolit dan mikroorganisme yang terdapat dalam tanah andisol membutuhkan waktu tertentu untuk melakukan dekomposisi.

Kecepatan pengisian yang akan digunakan dalam menentukan efisiensi sistem MSL harus memenuhi beberapa syarat antara lain nilai $\mathrm{pH}$, TSS, BOD dan COD harus sesuai dengan standar Baku Mutu Air Industri Tahu dan persentase penurunan rata-rata yang tinggi serta pertimbangan lain yang relevan. Pada Gambar 2 terlihat bahwa kecepatan pengisian yang memenuhi syarat adalah 160, 320 dan $480 \mathrm{~lm}^{-2}$ hari 1 . Persentase rata-rata penurunan nilai TSS yang paling tinggi diperoleh pada kecepatan $320 \mathrm{~lm}^{-2}$ hari $^{-1}$ yaitu $81,59 \%$, BOD diperoleh pada kecepatan pengisian $160 \mathrm{~lm}^{-2}$ hari $^{-1}$ sebesar 99,3\% dan COD diperoleh pada kecepatan pengisian 320 $\mathrm{lm}^{-2}$ hari $^{-1}$ sebesar 99,55 \%. Menurut Tahir et al. (1997), sistem MSL mempunyai persentase penurunan yang paling besar pada kecepatan pengisian $100-400 \mathrm{~lm}^{-2}$ hari $^{-1}$. dari 2 pertimbangan diatas, dipilih kecepatan pengisian optimum yang digunakan untuk menentukan efisiensi sistem MSL adalah $320 \mathrm{~lm}^{-2}$ hari $^{-1}$. pertimbangan lain memilih kecepatan pengisian $320 \mathrm{~lm}^{-2}$ hari $^{-1}$ adalah, dalam percobaan skala laboratorium, jika menggunakan kecepatan pengisian $160 \mathrm{~lm}^{-2}$ hari $^{-1}$ aliran limbah cair industri tahu ke dalam sistem MSL terlalu lambat padahal limbah cair industri tahu mudah mengental dan membusuk dalam waktu yang relatif singkat karena banyak mengandung zatzat organik terutama protein.

\section{Efisiensi Sistem MSL dalam Menurunkan Kadar TSS, BOD dan COD Limbah Cair Industri Tahu}

Sebelum digunakan untuk menentukan efisiensi, sistem MSL dikondisikan selama 1 minggu. Secara bertahap kecepatan pengisian diturunkan dari $800 \mathrm{~lm}^{-2}$ hari-1 sampai $320 \mathrm{~lm}^{-2}$ hari ${ }^{1}$. Efisiensi sistem MSL ditentukan pada kecepatan pengisian optimum $320 \mathrm{~lm}^{-2}$ hari $^{-1}$. Limbah cair industri tahu dialirkan ke dalam sistem MSL dengan kecepatan pengisian optimum $320 \mathrm{~lm}^{-2}$ hari $^{-1}$ selama 24 jam dalam 30 hari. Setiap 5 hari dilakukan pengukuran atau analisis kadar TSS, BOD dan COD sampai hari ke-30 sehingga diperoleh 6 hasil analisis untuk setiap parameter.

Tujuan dari sampling yang diteruskan dengan analisis setiap 5 hari sekali selama 30 hari adalah untuk mengetahui kemampuan sistem MSL dalam menurunkan kadar TSS, BOD dan COD pada limbah cair industri tahu. Berikut hasil analisis limbah cair industri tahu sebelum dan sesudah diolah menggunakan sistem MSL dengan kecepatan pengisian optimum $320 \mathrm{~lm}^{-2}$ hari $^{-1}$.

Berdasarkan Tabel 3, nilai $\mathrm{pH}$ dan BOD setelah diolah sudah memenuhi standar Baku Mutu Air Limbah dengan nilai $\mathrm{pH}$ 7,0 - 7,2 dan kadar BOD ratarata maksimum $130 \mathrm{mg} \mathrm{l}^{-1}$. Kadar TSS yang dihasilkan setelah diolah dengan sistem MSL sudah mendekati kadar TSS maksimum sebesar $100 \mathrm{mg} \mathrm{l}^{-1}$. Hasil analisis ini dapat disebabkan oleh beberapa hal antara lain air masih belum teruapkan semua, faktor alat pendingin (desikator) yang kemampuan menyerap air atau uap air sudah berkurang dan alat ukur yang kurang baik. Analisis COD limbah cair industri tahu pada 15 hari pertama masih diatas standar Baku Mutu 
Air Limbah dengan batas kadar COD maksimum $275 \mathrm{mg}^{-1}$ karena sistem MSL masih dalam masa adaptasi setelah digunakan pada kecepatan pengisian 800 $\mathrm{lm}^{-2}$ hari $^{-1}$ sehingga belum normal. Tetapi setelah 15 hari kadar COD mulai turun dan nilainya berada di bawah batas kadar COD maksimum.

Kadar BOD dan COD yang tinggi dalam limbah cair industri tahu menunjukkan bahwa limbah tersebut mengandung jumlah pencemar yang tinggi terutama pencemar yang disebabkan oleh bahan organik. Semakin tinggi jumlah bahan organik dalam limbah semakin besar pula nilai BOD dan COD sebab kebutuhan akan oksigen untuk menguraikan bahan organik tersebut semakin tinggi (PUSARPEDAL, 1996).

Tabel 3. Hasil analisis limbah cair industri tahu sebelum dan sesudah diolah dengan sistem MSL pada penentuan efisiensi sistem MSL

\begin{tabular}{|c|c|c|c|c|c|c|c|c|}
\hline \multirow{3}{*}{ Waktu Sampling } & \multicolumn{4}{|c|}{ Sebelum } & \multicolumn{4}{|c|}{ Sesudah } \\
\hline & \multirow[t]{2}{*}{$\mathrm{pH}$} & \multicolumn{3}{|c|}{$\begin{array}{l}\text { Konsentrasi rata-rata } \\
\left(\mathrm{mg} \mathrm{l}^{-1}\right)\end{array}$} & \multirow[t]{2}{*}{$\mathrm{pH}$} & \multicolumn{3}{|c|}{$\begin{array}{c}\text { Konsentrasi rata-rata } \\
\qquad\left(\mathrm{mg} \mathrm{l}^{-1}\right)\end{array}$} \\
\hline & & TSS & BOD & COD & & TSS & BOD & COD \\
\hline Hari ke 5 & 4,9 & 750 & 6060 & 7320 & 7,2 & 150 & 108,60 & 600 \\
\hline Hari ke 10 & 4,6 & 750 & 6150 & 14340 & 7,0 & 150 & 130,20 & 1458 \\
\hline Hari ke 15 & 4,8 & 810 & 6570 & 18000 & 7,2 & 180 & 27,60 & 360 \\
\hline Hari ke 20 & 4,5 & 690 & 6780 & 9720 & 7,0 & 150 & 63,75 & 216 \\
\hline Hari ke 25 & 4,9 & 680 & 10110 & 11160 & 7,1 & 150 & 60,60 & 198 \\
\hline Hari ke 30 & 4,9 & 810 & 6690 & 6780 & 7,1 & 150 & 51,00 & 162 \\
\hline
\end{tabular}

Efisiensi sistem MSL dapat ditentukan dari persentase rata-rata penurunan kadar TSS, BOD dan COD pada kecepatan optimum selama 30 hari.
Efisiensi sistem MSL dalam menurunkan kadar TSS, BOD dan COD limbah cair industri tahu ditunjukkan pada Tabel 4.

Tabel 4. Efisiensi sistem MSL dalam menurunkan kadar TSS, BOD dan COD limbah cair industri tahu

\begin{tabular}{lrrrrrrr}
\hline \multirow{2}{*}{ Parameter } & \multicolumn{6}{c}{ Penurunan Kadar (\%) } & Efisiensi sistem MSL \\
\cline { 2 - 6 } & \multicolumn{1}{c}{ T1 } & \multicolumn{1}{c}{ T2 } & \multicolumn{1}{c}{ T3 } & \multicolumn{1}{c}{ T4 } & \multicolumn{1}{c}{ T5 } & \multicolumn{1}{c}{ T6 } & \multicolumn{1}{c}{$(\%)$} \\
\hline TSS & 79,91 & 79,81 & 77,74 & 78,41 & 78,12 & 77,74 & 78,62 \\
BOD & 98,18 & 97,88 & 99,58 & 99,06 & 99,4 & 99,22 & 98,89 \\
COD & 91,79 & 89,78 & 98 & 97,77 & 98,2 & 97,61 & 95,53 \\
\hline
\end{tabular}

Keterangan : $\mathrm{T} 1=$ hari ke 5, T2 = hari ke 10, T3 = hari ke 15, T4 = hari ke 20, $\mathrm{T} 5=$ hari ke 25, dan T6 = hari ke 30

Berdasarkan Tabel 4, efisiensi sistem MSL cukup stabil dalam jangka waktu 30 hari. Persentase rata-rata penurunan kadar COD pada 10 hari pertama masih rendah, hal ini disebabkan oleh adaptasi sistem MSL terhadap kecepatan pengisian $320 \mathrm{~lm}^{-2}$ hari ${ }^{-1}$. Sistem MSL bekerja dengan sangat baik dalam menurunkan kadar BOD yaitu sebesar 98,89\%, kemudian COD 95,53 $\%$ dan TSS 78,62 \%. Ini berarti bahwa mikroorganisme dan zeolit dalam sistem MSL bekerja dengan baik melakukan dekomposisi limbah cair industri tahu.

Penurunan kadar TSS, BOD dan COD limbah cair industri tahu dengan 
metode Multi Soil Layering (MSL) memberikan suatu indikasi terjadinya degradasi limbah cair industri tahu oleh mikroorganisme yang terdapat dalam sistem MSL tersebut. Choliq (1992) menyatakan dalam proses pengolahan bahan organik limbah cair oleh mikroorganisme terdapat dua peristiwa yang sangat penting yaitu pemakaian oksigen oleh mikroorganisme untuk respirasi dan pembentukan sel mikroorganisme dengan memanfaatkan zat organik sebagai sumber makanan dan energi. Proses penguraian tersebut dapat digambarkan sebagai berikut :

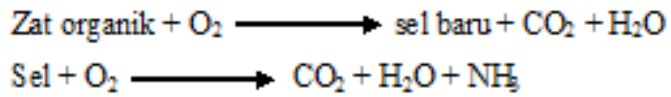

Mikroorganisme yang berperan dalam degradasi limbah cair industri tahu yang terdapat dalam sistem MSL, terdiri dari kelompok bakteri, fungi, plankton dan protozoa yang bersimbiosis secara mutualisme. Proses degradasi ini berlangsung secara berantai antara dua jenis mikroorganisme atau lebih. Mekanisme sistem MSL dalam pengolahan limbah cair industri tahu ditujukan pada Gambar 3.

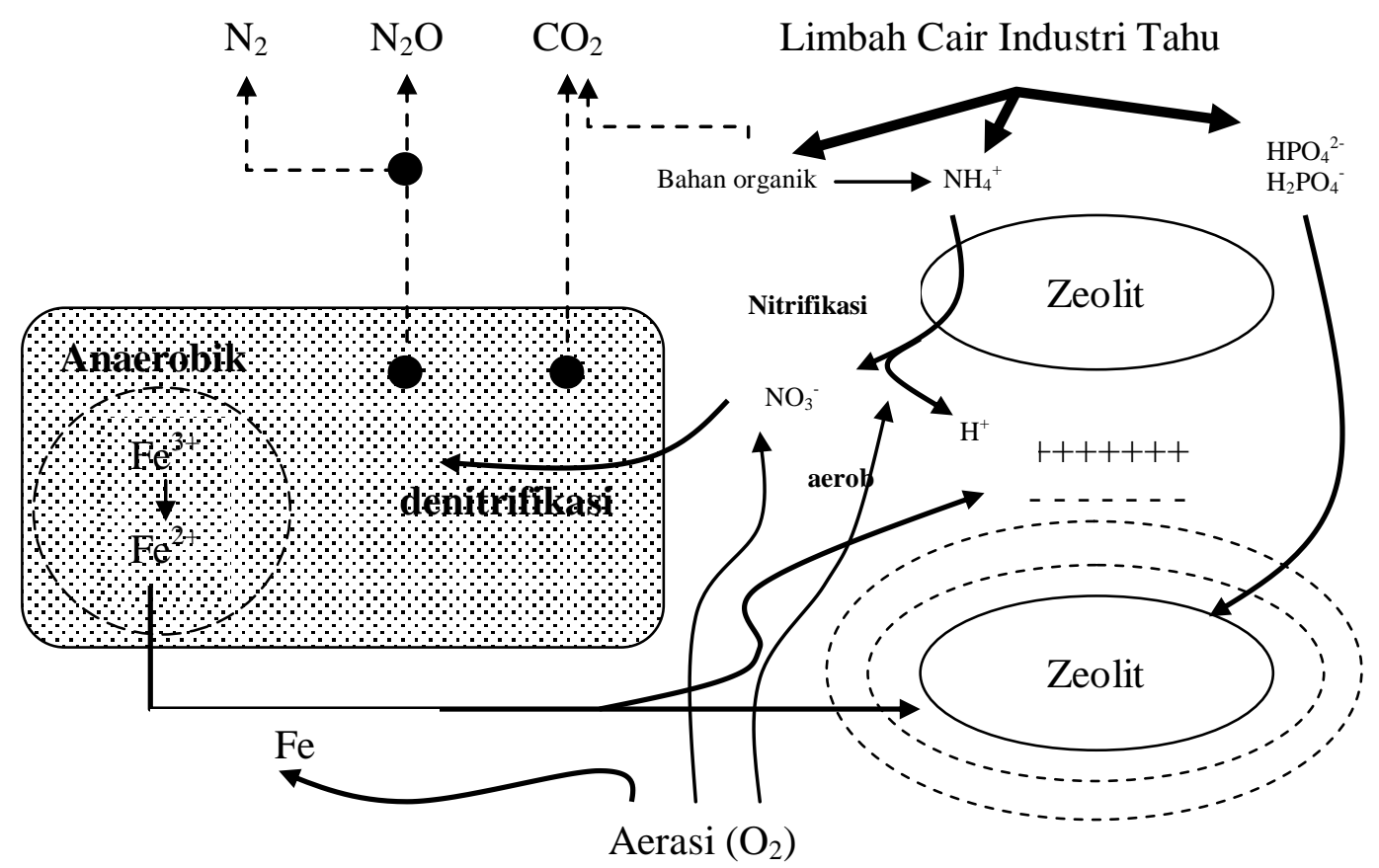

Gambar 3. Mekanisme Pengolahan Limbah Cair Industri Tahu dalam Sistem MSL Sumber : Tahir et al., 1997.

Menurut Tahir et al., (1997), dalam mekanisme sistem MSL (Gambar 3) terjadi dua kondisi yaitu aerobik dan anaerobik. Pada kondisi aerobik, yaitu pada lapisan zeolit dan tempat bertemunya lapisan zeolit dan tanah terjadi dekomposisi senyawa organik, fiksasi fosfat dan proses nitrifikasi. Denitrifikasi dan reduksi ion $\mathrm{Fe}^{3+}$ terjadi dalam kondisi anaerobik yang terjadi dalam lapisan tanah.

Pada kondisi aerob, nitrogenamonia $\left(\mathrm{NH}_{4}{ }^{-} \mathrm{N}\right)$ baik yang berasal dari limbah cair industri tahu maupun dari bahan organik yang berdekomposisi diadopsi oleh zeolit kemudian mengalami nitrifikasi menjadi $\mathrm{NO}_{3}{ }^{-}$dengan bantuan $\mathrm{O}_{2}$. reaksi nitrifikasi yang terjadi adalah : 
$2 \mathrm{NH}_{4}^{+}+3 \mathrm{O}_{2} \longrightarrow 2 \mathrm{NO}_{2}^{-}+2 \mathrm{H}_{2} \mathrm{O}+4 \mathrm{H}^{+}$(nitrit)

$2 \mathrm{NO}_{2}^{-}+\mathrm{O}_{2} \longrightarrow 2 \mathrm{NO}_{3}^{-}$(nitrat)

Nitrat hasil nitrifikasi secara bertahap bergerak ke dalam lapisan tanah campuran andisol dan arang, dan mengalami denitrifikasi menjadi $\mathrm{N}_{2} \mathrm{O}$. nitrogen oksida setelah mengalami denitrifaksi total akan menjadi $\mathrm{N}_{2}$. reduksi $\mathrm{N}_{2} \mathrm{O}$ inilah yang berhubungan dengan kadar nitrat dan COD. Arang tempurung kelapa yang dicampurkan ke dalam tanah andisol berperan sebagai sumber karbon dalam proses denitrifikasi tersebut. Logam besi $\mathrm{Fe}^{3+}$ yang terdapat dalam akan tereduksi menjadi ion $\mathrm{Fe}^{2+}$ dan secara bertahap ditransfer ke lapisan zeolit dimana ion tesebut berperan dalam proses adsorbsi fosfat.

Reaksi yang terjadi pada proses penguraian bahan organik baik secara aerob maupun anaerob menurut Hammer (1977) adalah sebagai berikut :

$$
\begin{array}{rll}
\text { Aerob }: & \text { senyawa organik }+\mathrm{O}_{2} \longrightarrow & \mathrm{CO}_{2}+\mathrm{H}_{2} \mathrm{O}+\mathrm{e} \\
\text { Anaerob : } & \text { senyawa organik }+\mathrm{NO}_{3}{ }^{-} \longrightarrow \mathrm{CO}_{2}+\mathrm{N}_{2}+\mathrm{e} \\
& \text { senyawa organik }+\mathrm{SO}_{4} \longrightarrow \mathrm{CO}_{2}+\mathrm{H}_{2} \mathrm{~S}+\mathrm{e} \\
& \text { senyawa organik } \longrightarrow \text { asam-asam organik }+\mathrm{CO}_{2}+\mathrm{H}_{2} \mathrm{~S}+\mathrm{e} \\
& \text { asam-asam organik } \longrightarrow \mathrm{CH}_{4}+\mathrm{CO}_{2}+\mathrm{e}
\end{array}
$$

\section{KESIMPULAN}

Berdasarkan hasil penelitian dan pembahasan di atas dapat disimpulkan beberapa hal antara lain :

1. Metode Multi Soil Layering (MSL) dapat digunakan sebagai metode alternatif dalam pengolahan limbah cair industri tahu untuk menurunkan kadar TSS, BOD dan COD.

2. Kecepatan pengisian optimum limbah cair ke dalam sistem MSL adalah 320 $1 \mathrm{~m}^{-2}$ hari $^{-1}$.

3. Efisiensi sistem MSL dalam penurunan kadar TSS, BOD dan COD limbah cair masing-masing sebesar 78,62 \%, 98,89\% dan 95,53 $\%$.

\section{DAFTAR PUSTAKA}

APHA. 1995. Standard Method for the Examination of Water and Wastewater, $19^{\text {th }}$ ed. American Public Health Association, Washington
Bapedalda DKI Jakarta. 2000. Buku Pedoman Penyusunan NKLD DKI Jakarta 2000.(on-line). Bapedalda DKI. http :// www.dki.go.id/bapedalda/BukuII.htm.diakses 10 Juni 2004

Bapedalda Jateng. 2004. Peraturan Daerah Propinsi Jawa Tengah nomor 10: tentang Baku Mutu Air Limbah, Bapedalda Propinsi Jawa Tengah

Choliq, A.U., 1992. Pengolahan Limbah Organik dengan Sistem RBC, Proceeding Seminar Nasional Pengelolaan Lingkungan Tantangan Masa Depan. Jurusan Teknik Lingkungan ITB. Bandung

Hammer, M. J. 1977. Water and Wastewater Tecnology. Jhon Wiley and Sons Inc., Newyork

Isoo, F., T. Shibata and T. Okonogi. 1976. Treatment of Dyeing Waste 
Liquor with Waste Sludge from Aluminium Production Factory, Pollution Control, 47 :

Luanmanee, S., B. Saitthiti, C. Panichajakul, and T. Wakatsuki. 2000. Efficiency of The Multi Soil Layering Systems with Various Organic Material Components on Domestic Wastewater Treatment. Paper Submitted on Managing Water and Waste in The New Millenium, May 23 - 26, Johannesburg

Masunaga, T., K. Sato, T. Zennami, S. Fujii, and T. Wakatsuki. 2001. Application of The Multi Soil Layering Method to Direct Treatment of Polluted River Water. Proceedings of The First IWA Asia- Pacific Regional Conference, September 12 15, Japan . P.6

Poerwadi, B., Pariadi. Budi, dan K., Ariseno. 1998. Pemanfaatan Zeolit Alam Indonesia Sebagai Adsorben Limbah Cair dan Fluidisasi Dalam Kolom Fluidisasi. Majalah Ilmiah UNSOED. Purwokerto.

Pusat Sarana Pengendalian Dampak Lingkungan (PUSARPEDAL). 1996. Materi Ajar Pelatihan Analisis Kualitas Air dan Limbah Cair Tahap III. Pengendalian Dampak Lingkungan, Jakarta

Radar Banyumas. 6 September 2005. Perajin Tahu Kesulitan Kelola Limbah Air. Hlm 4

Tahir, Y. T. Harada and T. Wakatsuki. 1997. Enhancement and Control of the Funtions of Soil Resources for Biogenik Wastewater Treatment by Multi Soil Layering
Method. In Te Forth Internasional Conference of East Federation of Soil Science Societies. "Soil Quality Management and AgroEcosystem Health”. P. 241-252. Cheju, Korea

Wakatsuki, T., H. Esumi, and S.Omura. 1993. High Performance and N \& $\mathrm{P}$ Removable on -site Domestic Wastewater Treatment System by Multi Soil Layering Method. Wat. Sci. Tech. $27: 31-40$

Wakatsuki, T., S. Luanmanee, T. Masunaga, and $\mathrm{T}$. Attanandana.2001. High Grade On-Site Treatment of Domestic Wastewater And Polluted River Water By Multi-Soil Layering Method. Ecological Engineering, Elsevier (in press). 